\title{
Effect of sweet biscuits on the incidence of dental caries in rats
}

\author{
By T. H. GRENBY AND FRANCES M. PATERSON \\ Department of Oral Medicine and Pathology, Guy's Hospital Dental School, \\ London $S E_{\mathrm{I}}$
}

(Received 4 May I97I - Accepted I6 June 197I)

\begin{abstract}
1. Biscuits baked to a recipe requiring only sucrose, white flour and water were ground to a powder and mixed with the remaining ingredients of a standard rat diet. The control diet contained the same dry-weight amounts of all ingredients, but the sucrose and flour were not baked into biscuits. Eighty-four rats were divided into two matched groups and fed on the diets for 8 weeks from weaning.

2. The biscuit diet produced significantly more caries than the control diet, with a total of about twice as many lesions, and also many more advanced lesions. Nearly all the lesions were in the molar fissures, suggesting that the cooked and powdered biscuit was impacted and retained in the fissures.
\end{abstract}

It is well known that sucrose, glucose and certain other sugars in food can cause dental caries in experimental animals (Shafer, 1949; Gustafson, Stelling, Abramson \& Brunius, 1955; Grenby \& Hutchinson, 1969; Green \& Hartles, 1969). The sugars are generally believed to act as substrates from which certain oral bacteria produce the acids that play an important part in the development of carious lesions. Sucrose is believed to be the most cariogenic of the sugars (see Grenby, $1967 a$, for references), possibly because it can be used as a substrate by certain oral bacteria not only to produce acid, but also to synthesize extracellular polysaccharide material that helps to constitute the dental plaque.

The acids create the maximum damage when they are formed close to the tooth surface and cannot diffuse away. Such a situation may arise in the fissures of the molar and premolar teeth when sugary foods and, of course, bacteria are impacted, and also in interproximal areas or along the gingival margin, where food residues or dental plaque may cling to the tooth surface undisturbed.

Thus, besides its sugar content, the cariogenicity of an individual food may depend on its adhesiveness to the tooth surface and its texture, which will determine its tendency to pack into the molar fissures when mixed with saliva. Finely ground diets were observed to initiate more carious lesions in rats than coarse-particle diets (König, I962). Several types of tests in vitro have been devised to relate the stickiness of foods to their 'caries-potential' (cf. Caldwell, I962; see Grenby, I969a, for further references), but only recently have animal experiments in this field been carried out, and some of the earliest results failed to show any increase in caries when sugary diets were given to rats as a sticky paste or as toffee instead of in powder form (Grenby, I969 $b$, I97I).

Another class of foods suspected of contributing to caries are sweet biscuits (cookies). Various types of biscuits were tested in rats by Ishii, König \& Mühlemann (I968). 
Examples of semi-sweet biscuits containing 10 and $22 \%$ sugars were tested at a level of $67 \%$ in the diet of rats by Green \& Hartles ( $1966 a$ ), and proved to be less cariogenic than the same quantity of sucrose. These biscuits were manufactured by an undisclosed commercial process, however, and contained as much as $14.4-17 \%$ fat. The presence of $5-10 \%$ fat in the diet has been shown to reduce caries in rodents (see, for example, Green \& Hartles, I966 $b$ ). In the present study therefore biscuits were made from sugar, white flour and water only, so as to correspond in texture to a high-sugar 'sugar-glass' or 'ginger-nut' type. To investigate the effect of cooking the sugar and flour together, the biscuit diet was compared simultaneously with a similar diet containing the same amounts of sugar and flour in their original uncooked form.

\section{METHODS}

Diets. The recipe for the biscuits was adapted from Bohn (1957). White flour, I $192 \mathrm{~g}$, and caster sugar (sucrose), 68I g, were mixed slowly in a Hobart rotary mixer, then $400 \mathrm{ml}$ water were added slowly with continuous mixing. The dough formed was kneaded for $5 \mathrm{~min}$, then it was rolled to about $0.7 \mathrm{~cm}$ thick, cut and baked at $190^{\circ}$ for $40 \mathrm{~min}$. After cooling, this produced a hard, close-textured sweet biscuit, which was ground to a fine, floury powder by a hammer-mill with a $0.8 \mathrm{~mm}$ sieve. The powder contained $(\%)$ : non-reducing sugar (sucrose) 38.5 ; reducing sugars 0.9 ; water 3.7 .

The powdered biscuit was incorporated in a diet of the following percentage composition: biscuit 66 (baked from sucrose 24 and white flour 42 ); skim-milk powder 32 ; dried liver powder 2. The control diet was identical in composition except that the sucrose and white flour were not baked into biscuits. Thus both diets were in the form of fine, dry powders.

Animals. Two experiments were carried out using two different strains of rat, Wistar and Osborne-Mendel (see Grenby, $1967 b$ ). The rats from each strain were divided into two groups each containing forty-two animals, and were completely matched for sex, age, strain and parentage. The groups were given the test and control diets $a d l i b$. for 8 weeks from weaning. Tap-water was supplied as drinking fluid and was always available to the rats. The rats were weighed weekly.

Assessment of caries. At the end of the experiments the mandibles were dissected out, and the molar tceth were examined for caries by the standard method of Shaw, Schweigert, McIntire, Elvehjem \& Phillips (I944), but modified to take into account interproximal and 'smooth-surface' lesions and also lesions in any of the smaller occlusal fissures apart from the six main ones (Grenby, I970). The carious lesions were each given a score between $I$ and 5 , depending on how far they had progressed, with 5 being the most advanced; a caries score for each animal was thus obtained. The total number of lesions and the total number of gross cavities in each animal were also counted.

\section{RESULTS}

Weight gains. The results of the two experiments are shown in Table $\mathrm{I}$, which includes the weight gains over the entire 8-week experimental period. The rats grew very well on both diets, but the weight gains were marginally greater on the 
control diet than on the biscuit diet. The Osborne-Mendel strain grew faster than the Wistar.

Caries. The mean caries scores and their standard errors are also shown in Table I. The results are arranged to compare matched groups of both sexes within each strain. As in earlier experiments, the level of caries was higher in the Osborne-Mendel strain than in the Wistar, particularly on the biscuit diet. On statistical analysis by Wilcoxon's Signed Ranks Test, the difference in mean caries scores between the biscuit and control diets was significant in all four groups $(P<0.05$ in the Wistar females; $P<0.02$ in the Wistar males and Osborne-Mendel males; $P<0.002$ in the Osborne-Mendel females).

Table 1. Mean weight gains, mean caries scores with their standard errors, total numbers of lesions and of gross cavities in two strains of rats fed on a biscuit diet or on a control diet

(Wistar, eleven male and ten female rats were fed on the biscuit and control diets respectively; OsborneMendel, eight male and thirteen female rats were fed on the biscuit and control diets respectively)

\begin{tabular}{|c|c|c|c|c|c|c|c|c|}
\hline \multirow[b]{2}{*}{ Strain } & \multicolumn{2}{|c|}{ Weight gain (g) } & \multicolumn{2}{|c|}{ Mean caries score $\pm \mathrm{SE}$} & \multicolumn{2}{|c|}{ No. of lesions } & \multicolumn{2}{|c|}{$\begin{array}{c}\text { No. of } \\
\text { gross cavities }\end{array}$} \\
\hline & $\begin{array}{l}\text { Biscuit } \\
\text { diet }\end{array}$ & $\begin{array}{l}\text { Control } \\
\text { diet }\end{array}$ & $\begin{array}{l}\text { Biscuit } \\
\text { diet }\end{array}$ & $\begin{array}{l}\text { Control } \\
\text { diet }\end{array}$ & $\begin{array}{l}\text { Biscuit } \\
\text { diet }\end{array}$ & $\begin{array}{l}\text { Control } \\
\text { diet }\end{array}$ & $\begin{array}{c}\text { Biscuit } \\
\text { diet }\end{array}$ & $\begin{array}{l}\text { Control } \\
\text { diet }\end{array}$ \\
\hline \multicolumn{9}{|l|}{ Wistar } \\
\hline Males & 180 & I 85 & $13.2 \pm 2.9^{*}$ & $5.5 \pm 0.8$ & 86 & 42 & 15 & 2 \\
\hline Females & 116 & 123 & $13.7 \pm 3 \cdot 4$ & $4 \cdot 4 \pm I \cdot I$ & 86 & 35 & 9 & I \\
\hline \multicolumn{9}{|c|}{ Osborne-Mendel } \\
\hline Males & 199 & 206 & $21 \cdot 3 \pm 3 \cdot 3^{*}$ & $8 \cdot 0 \pm I \cdot 5$ & 85 & $4^{6}$ & 28 & I \\
\hline Females & 138 & 152 & $19.8 \pm 4.3 * *$ & $5 \cdot 9 \pm 1 \cdot 1$ & I 24 & 60 & 29 & 0 \\
\hline
\end{tabular}

The effect of the diets on caries is also clearly shown in the total number of lesions in each group. In all four groups of animals roughly twice the number of lesions were observed on the biscuit diet as on the control diet. There was also a striking difference in the number of advanced lesions (score 3 or more by Shaw's method): a total of eighty-one gross cavities was recorded on the biscuit diet, compared with only four on the control diet. These differences were significant at a level of $P=0.0 \mathrm{r}$.

Nearly all the lesions were in the molar fissures. A small number of 'smooth-surface' lesions were observed, generally along the gingival margin, and although in three of the four groups the numbers were higher on the biscuit diet than on the control, there were too few lesions of this type to distinguish between the two diets on this basis.

\section{DISCUSSION}

The results show that the biscuits, made from sugar, flour and water, with no other additions, were more cariogenic than the same ingredients not cooked or processed in any way. Although the incidence of caries was very heavy on the biscuit diet, very few lesions developed interproximally or at the gingival margin, so it seems that the effect of the biscuits is to impact in the fissures, possibly providing a suitable environment for cariogenic bacterial processes. Another contributory factor may be the nature of 
the oral bacterial flora in these animals, which may favour the production of lesions in the fissures rather than at other sites on the teeth.

The level of caries may also have been influenced by changes in the eating pattern resulting from the replacement of uncooked flour and sugar by powdered biscuit, but no record of the frequency of eating was kept in these experiments.

Very little precise information is available on the effect of the texture of foods on dental caries, but it is commonly held that sticky foods are likely to be more cariogenic than those which can be removed from the teeth more easily. These sticky foods fall into two main classes. In the first, the foods have a high sugar content, which contributes to their stickiness. Both sucrose and glucose are very highly soluble in water and can form thick syrups in high concentration. These are used as the basis of a wide range of confectionery, suspected of being among the most cariogenic foods. However, neither toffee nor sweet syrups proved as cariogenic as powdered foods of the same sugar content, when tested in rodents (Grenby, $1969 b, 197 \mathrm{r}$ ).

The second main class of sweet, sticky foods consists of foods containing both sugar and a cereal product, including many baked foods such as biscuits. Cereal foods alone, in the absence of sugar, generally produce little caries (König, 1967; Grenby, I966). A diet containing gluten, the adhesive protein of flour, together with $10 \%$ sucrose also produced very little caries (Grenby, I $969 a$ ). In the present work, however, the sucrose content of the diet was raised to $24 \%$. When this sugar, together with $42 \%$ white flour, was incorporated uncooked in rat diets, the level of caries was low to moderate, but when the sugar and flour were baked into biscuits, the caries incidence rose to a significantly higher level. Inversion of, or other attack on, the sucrose was not responsible for this, since nearly all the sugar in the biscuits had remained in the form of sucrose, without inversion to reducing sugars.

Microscopic examination of the powdered biscuit after staining with Congo red showed that a high proportion of the starch granules had been ruptured by the cooking procedure, and that large numbers of the disrupted granules had aggregated together. It has previously been shown that these changes on cooking wheat starch in the absence of sugar, did not make it more cariogenic (Grenby, 1965 ). The powdered biscuit contained $39.4 \%$ of sugars, however, and its high cariogenicity may result from the altered physical properties of the starch increasing the retention of the sugar in the fissures of the molar teeth, where most of the carious lesions developed.

We are grateful to the Flour Milling and Baking Research Association for information, particularly to $\mathrm{Mr} \mathrm{H}$. V. Hart for his analyses of the biscuits, to Miss P. Newlands and the staff of the Guy's Hospital Dietetics Department for cooking facilities, and to Mrs W. R. Fox for advice on statistics.

\section{REFEREN CES}

Bohn, R. M. (1957). Biscuit and Cracker Production Ist ed. New York: American Trade Publishing Co. (N.Y.).

Caldwell, R. C. (1962). F. dent. Res. 4I, 821 .

Green, R. M. \& Hartles, R. L. (1966a). Br. F. Nutr. 20, 317. 
Green, R. M. \& Hartles, R. L. (1966b). Archs oral Biol. I1, 913.

Green, R. M. \& Hartles, R. L. (1969). Archs oral Biol. 14, 235.

Grenby, T. H. (1965). Archs oral Biol. I0, 433.

Grenby, T. H. (1966). Br. dent. J. 121, 26.

Grenby, T. H. (1967a). Caries Res. I, 208.

Grenby, T. H. (1967b). Helv. odont. Acta I I, 43 .

Grenby, T. H. (1969a). Archs oral Biol. 14, 1253.

Grenby, T. H. (1969b). Archs oral Biol. 14, 1259.

Grenby, T. H. (1970). Br. dent. F. 128, I.

Grenby, T. H. (1971). Caries Res. (In the Press.)

Grenby, T. H. \& Hutchinson, J. B. (1969). Archs oral Biol. 14, 373.

Gustafson, G., Stelling, M., Abramson, E. \& Brunius, E. (1955). Odont. Tidskr. 63, 506.

Ishii, T., König, K. G. \& Mühlemann, H. R. (1968). Helv. odont. Acta 12, 41.

König, K. G. (1962). F. dent. Res. 4r, 966.

König, K. G. (1967). Br. dent. F. 123, 585 .

Shafer, W. G. (1949). Science, N.Y. rxo, 143.

Shaw, J. H., Schweigert, B. S., McIntire, J. M., Elvehjem, C. A. \& Phillips, P. H. (I944). F. Nutr. 28, 333. 